\title{
Pilotna raziskava psihometričnih lastnosti vprašalnikov SF-36v2 in ESRD-SCL-TM za merjenje z zdravjem povezane kakovosti življenja bolnikov po presaditvi ledvice
}

\author{
Bernarda Logar Zakrajšek ${ }^{1^{*}}$, Andrej Bren², Gregor Sočan ${ }^{3}$ in Jernej Pajek ${ }^{2}$ \\ ${ }^{1}$ Upravljanje in vodenje, Kirurška klinika, Univerzitetni klinični center Ljubljana \\ ${ }^{2}$ Klinični oddelek za nefrologijo, Univerzitetni klinični center Ljubljana \\ ${ }^{3}$ Oddelek za psihologijo, Filozofska fakulteta, Univerza v Ljubljani
}

\begin{abstract}
Povzetek: Namen pričujoče raziskave je bil preveriti psihometrične lastnosti slovenskih priredb vprašalnikov za merjenje z zdravjem povezane kakovosti življenja SF-36v2 ${ }^{\circledR}$ in ESRD-SCL-TM na vzorcu bolnikov po presaditvi ledvice. Oseminpetdeset stabilnih bolnikov iz edinega slovenskega centra za presaditev ledvice je na vprašalnika odgovarjalo dvakrat v razmiku 14-21 dni. Sočasno smo pri bolnikih izmerili zdravstvene kazalce, ki se povezujejo z delovanjem presajene ledvice in splošnim zdravstvenim stanjem. Rezultati kažejo dobro notranjo zanesljivost posameznih lestvic obeh vprašalnikov. Zanesljivost $\mathrm{v}$ času je bila zadovoljiva za vprašalnik ESRD-SCL-TM, ne pa tudi za vprašalnik SF-36v2 ${ }^{\circledR}$. Lestvice obeh vprašalnikov, ki merijo sorodne konstrukte, smiselno korelirajo med seboj ter s pričakovanimi demografskimi (spol, izobrazba) in zdravstvenimi spremenljivkami (hemoglobin, kreatinin, število zdravil). Slovenski verziji vprašalnikov SF-36v2 ${ }^{\circledR}$ in ESRD-SCL-TM imata zadovoljive merske lastnosti (z izjemo stabilnosti $\mathrm{v}$ času pri vprašalniku SF-36v2 ${ }^{\circledR}$ ) za merjenje z zdravjem povezane kakovosti življenja pri bolnikih po presaditvi ledvice.
\end{abstract}

Ključne besede: z zdravjem povezana kakovost življenja, presaditev ledvice, SF-36v2 ${ }^{\circledR}$, ESRD-SCL-TM, sestava testa

\section{A pilot study of psychometric characteristics of questionnaires SF-36v2 and ESRD-SCL-TM measuring health related quality of life in kidney transplant recipients}

\author{
Bernarda Logar Zakrajšek ${ }^{1 *}$, Andrej Bren ${ }^{2}$, Gregor Sočan ${ }^{3}$ and Jernej Pajek ${ }^{2}$ \\ ${ }^{1}$ Management, Division of Surgery, University Medical Centre Ljubljana, Slovenia \\ ${ }^{2}$ Department of Nephrology, University Medical Centre Ljubljana, Slovenia \\ ${ }^{3}$ Department of Psychology, Faculty of Arts, University of Ljubljana, Slovenia
}

\begin{abstract}
The aim of this study was to assess psychometric characteristics of Slovenian versions of two self-administered questionnaires of health related quality of life SF-36v $2^{\circledR}$ and ESRD-SCL-TM in kidney transplant patients. Fifty eight stable kidney transplant recipients from the only transplant centre in Slovenia responded to the questionnaires two times with 14-21 days in between. At the same time health measures related to kidney functioning and general health were checked. The results show acceptable internal reliability of all dimensions of the two questionnaires. Dimensions of both questionnaires that measure similar constructs correlate appropriately to support the construct validity as well as with expected demographic (gender, education) and clinical variables (haemoglobin, creatinine, number of medications taken daily). Slovenian versions of SF-36v2 ${ }^{\circledR}$ and ESRD-SCL-TM showed satisfactory results in measuring health related quality of life in kidney transplant patients with the exception of test-retest reliability in SF-36v2 ${ }^{\circledR}$.
\end{abstract}

Key words: health related quality of life, kidney transplantation, SF-36v2 ${ }^{\circledR}$, ESRD-SCL-TM, test construction

\footnotetext{
*Naslov/Address: mag. Bernarda Logar Zakrajšek, Upravljanje in vodenje, Kirurška klinika, Univerzitetni klinični center Ljubljana, Zaloška 7, 1000 Ljubljana, e-mail: bernarda.logar@kclj.si
}

Članek je licenciran pod pogoji Creative Commons Attribution 4.0 International licence. (CC-BY licenca). The article is licensed under a Creative Commons Attribution 4.0 International License (CC-BY license). 
Z zdravjem povezana kakovost življenja se nanaša na posameznikovo oceno ali vrednotenje pomembnih vidikov njegovega blagostanja, na katere vpliva trenutna bolezen in/ali zdravljenje (Bottomley, Jones in Claassens, 2009). Z zdravjem povezana kakovost življenja opisuje subjektivne izkušnje, stanja in zaznave posameznikovega blagostanja, ki vključujejo fizične, psihološke in socialne vidike (Revicki idr., 2001). To je nekaj desetletij star, vendar aktualen koncept na področju zdravljenja bolnikov, saj velja za enega ključnih pokazateljev uspešnosti zdravljenja (Keown, 2001).

Pri bolnikih s kronično ledvično boleznijo je z zdravjem povezana kakovost življenja pogosto zmanjšana glede na splošno populacijo (Finkelstein, Wuerth in Finkelsten, 2009; Soni, Weisbord in Unruh, 2010). Kroničnim ledvičnim bolnikom s končno odpovedjo delovanja ledvic sta na voljo dve obliki zdravljenja: dializno zdravljenje ali presaditev ledvice. Večina dializnih bolnikov izbere presaditev ledvice $\mathrm{v}$ upanju, da se jim bo kakovost življenja izboljšala. Življenjsko zadovoljstvo, telesno in duševno blagostanje in sposobnost, da se vrnejo na delo, so boljši pri bolnikih po presaditi kot pri bolnikih na dializi (Danovitch, 2010; Painter, Krasnoff, Kuskowski, Frassetto in Johansen, 2012; Tonelli idr., 2011). $\mathrm{V}$ naši prejšnji retrospektivni raziskavi smo $\mathrm{z}$ uporabo enostavne petstopenjske lestvice ugotovili boljšo kakovost življenja pri bolnikih po presaditvi ledvice glede na obdobje zdravljenja $\mathrm{z}$ dializo (Logar, 2005). Življenje po presaditvi prinaša tudi tveganja, ki lahko pomembno zmanjšajo kakovost življenja. Z vidika bolnikovega doživljanja $\mathrm{v}$ tem kontekstu izstopajo stranski učinki imunosupresivne terapije in strah pred zavrnitvijo presajenega organa (Logar, 2005; Rainer, Thompson in Lambros, 2010; Wainwright, 1999).

\section{Merjenje z zdravjem povezane kakovosti življenja}

Za merjenje z zdravjem povezane kakovosti življenja je na voljo več različnih vprašalnikov, ki jih delimo na splošne in specifične (Avramovic in Stefanovic, 2012; Glover, Banks, Carson, Martin in Duffy, 2011; Rifel, 2006). Splošni se uporabljajo pri različnih boleznih in stanjih, pri različnih zdravstvenih ukrepih ali pri različnih populacijah, kar omogoča primerjavo med njimi. Specifični vprašalniki se uporabljajo pri posameznih boleznih ali populacijah bolnikov in so zato bolj usmerjeni na prav določeno simptomatiko, ki vpliva na kakovost življenja (Avramovic in Stefanovic, 2012; Glover idr., 2011; Rifel, 2006).

Najpogosteje uporabljeni splošni vprašalniki z zdravjem povezane kakovosti življenja so Kratka oblika vprašalnika zdravja SF-36v2 ${ }^{\circledR}$ (angl. Short Form-36, Second version), Nottinghamski zdravstveni profil (angl. Nottingham Health Profile - NHP) in Profil vpliva bolezni (angl. Sickness impact profile - SIP) (Fiebiger, Mitterbauer in Oberbauer, 2004; Rifel, 2006). Gre za večdimenzijske vprašalnike, ki na posameznih lestvicah opredeljujejo $\mathrm{z}$ zdravjem povezano kakovost življenja. Kratka oblika vprašalnika zdravja SF$36 \mathrm{v} 2^{\circledR}$ izhaja iz štiriletne raziskave (angl. Medical Outcome Study - MOS), v kateri so raziskovali vpliv značilnosti bolezni, zdravstvenega sistema in bolnikov na rezultate zdravljenja. Iz nabora 149 vprašanj so jih izbrali 36 , ki so bila najboljši pokazatelj kakovosti življenja. Vprašalnik v vsebinskem smislu pokriva osem področij zdravja, ki se združujejo v dve nadredni komponenti: telesno in duševno. Telesno komponento sestavljajo lestvice: Telesna zmogljivost, Omejitve telesne zmogljivosti, Telesna bolečina in Splošno zdravje. Duševno komponento sestavljajo lestvice: Duševno zdravje, Čustvene težave, Socialno funkcioniranje in Vitalnost. Vprašalnik ima več različno dolgih verzij (SF20, SF-12, SF-36v2 ${ }^{\circledR}$ ). Preveden je v 140 jezikov, $\mathrm{z}$ njegovo uporabo je bilo do leta 2011 objavljenih več kot 17.000 kliničnih študij (Maruish, 2011).

Avtorji vprašalnika SF-36v2 ${ }^{\circledR}$ navajajo visoko notranjo zanesljivost posameznih lestvic. Ob zbiranju norm na splošni ameriški populaciji leta $2009(N=4024)$ so znašali koeficienti zanesljivosti (alfa) med 0,82 in 0,96 (Maruish, 2011). Prav tako so zanesljivost lestvic preverjali na nekaj kliničnih populacijah, kjer so znašali koeficienti notranje zanesljivosti za posamezne lestvice na vzorcu ledvičnih bolnikov od 0,79 do 0,96 (Maruish, 2011). Zanesljivost v času so preverjali v isti raziskavi na manjšem vzorcu $(N=147)$, ko so preizkušanci vprašalnik izpolnili dvakrat v razmiku približno 15 tednov. Koeficienti zanesljivosti v času so se za posamezne lestvice gibali pri ledvičnih bolnikih od 0,70 do 0,88 (Maruish, 2011).

$\mathrm{V}$ slovenskem prostoru je objav $\mathrm{z}$ uporabo tega vprašalnika malo. Marn-Vukadinović in Jamnik (2011) sta preverjali veljavnost in zanesljivost vprašalnika na vzorcu bolnikov s športno poškodbo kolena. Koeficienti alfa so bili na posameznih lestvicah višji od 0,78 . Intraklasni koeficienti, $\mathrm{s}$ katerimi sta preverjali zanesljivost $\mathrm{v}$ času, so znašali od 0,80 do 0,93 .

Sonc, Vidmar in Hlebš (2010) so uporabili SF-36v2 ${ }^{\circledR}$ kot kriterij za potrditev konvergentne in diskriminativne veljavnosti za v slovenščino prevedeni vprašalnik o vplivu fibromialgije. Brejc (2006) je vprašalnik uporabil pri analizi vpliva zaznav zdravja in zloma kolka na strategije obvladovanja bolezni pri starejših poškodovancih. Bregant, Neubauer in Derganc (2012) so $\mathrm{z}$ vprašalnikom merili kakovost življenja pri mladostnikih, ki so utrpeli neonatalno encefalopatijo. Vprašalnik SF-36v $2^{\circledR}$ je je bil uporabljen tudi $\mathrm{V}$ nekaj raziskavah pri izdelavi diplomskih in magistrskih nalog (Rutar, Musek in Tušak, 2007; Svetičič in Praper, 2010; Žabjek, 2009).

Za bolnike po presaditvi ledvice je bilo v preteklosti razvitih nekaj specifičnih vprašalnikov $\mathrm{z}$ zdravjem povezane kakovosti življenja. Laupacis idr. (1993) so objavili Vprašalnik o presaditvi ledvice (angl. Kidney Transplant Questionnaire), ki meri pet dimenzij kakovosti življenja: Fizični simptomi, Utrujenost, Negotovost, Videz in Čustvovanje. Pomanjkljivost vprašalnika je, da so rezultati na lestvici Fizičnih simptomov specifični za posameznega bolnika, saj je to vprašanje pol odprto in bolnik sam navede zanj obremenjujoče simptome. Zaradi opisanega je primerjava med bolniki otežena. Parfrey idr. (1989) so razvili vprašalnik za primerjavo različnih oblik zdravljenja končne odpovedi delovanja ledvic, vključujoč zdravljenje s presaditvijo, vendar pa vprašalnik v vsebinskem smislu ne pokriva možnih stranskih učinkov imunosupresivne terapije, ki pomembno vplivajo na kakovost življenja. Hays in soavtorji so oblikovali vprašalnik Kakovost življenja pri 
ledvični bolezni (angl. Kidney Disease Quality of Life), ki je bil prvenstveno razvit za bolnike na dializi (Hays, Kallich, Mapes, Coons in Carter, 1994). Nekajkrat so ga uporabili za primerjavo med bolniki z različnimi oblikami nadomestnega zdravljenja, tudi za tiste po presaditvi, vendar podobno kot ostali vprašalniki ni posebej prilagojen tej populaciji.

Nemški raziskovalci (Franke idr., 1999) so prav z namenom zapolniti vrzel na tem področju razvili specifični vprašalnik kakovosti življenja, ki so ga poimenovali Lestvica končne odpovedi ledvic - oblika za presaditev - ESRD-SCL-TM (angl. The End-Stage Renal Disease Symptom Checklist - Transplantation Module), ki je kratek in enostaven. Vprašalnik obsega možne stranske učinke imunosupresivne terapije, telesne simptome po presaditvi in s presaditvijo povezane stresorje. $\mathrm{Na}$ osnovi faktorske analize so avtorji simptome razvrstili v šest lestvic, ki so jih poimenovali: Omejena telesna zmogljivost, Omejene kognitivne zmožnosti, Srčna in ledvična disfunkcija, Stranski učinki kortikosteroidov, Poraščenost in spremembe dlesni ter S presaditvijo povezan stres. Franke s soavtorji (1999) navaja, da so se na vzorcu bolnikov po presaditvi ledvice $(N$ $=458$ ) koeficienti notranje zanesljivosti alfa gibali med 0,76 in 0,85 za posamezne lestvice. Zanesljivost v času so merili s korelacijami na vzorcu 88 stabilnih bolnikov, ki so vprašalnik ponovno izpolnili po enem letu. Korelacijski koeficienti so na posameznih lestvicah znašali od 0,70 do 0,75 , le na lestvici Poraščenost in spremembe dlesni je bil korelacijski koeficient nižji $(r=0,48)$. Vprašalnik je $\mathrm{v}$ originalu pokazal smiselne in primerno visoke korelacije tudi z vprašalnikom SF-36v2 ${ }^{\circledR}$, kar potrjuje njegovo sočasno veljavnost.

$\mathrm{Na}$ Kliničnem oddelku za nefrologijo UKC Ljubljana načrtujemo prvo reprezentativno slovensko raziskavo o z zdravjem povezani kakovosti življenja pri bolnikih po presaditvi ledvice. Pri tem nameravamo $\mathrm{z}$ zdravjem povezano kakovost življenja meriti s splošnim in specifičnim vprašalnikom, kar bi nam omogočilo primerjave $\mathrm{z}$ rezultati v tujini. V Centru za presaditev ledvic smo spomladi 2014 izvedli pilotno raziskavo $\mathrm{z}$ namenom preverjanja veljavnosti in zanesljivosti dveh vprašalnikov. Izbrali smo splošni vprašalnik SF-36v2 ${ }^{\circledR}$ in ESRD-SCL-TM, ki meri specifično kakovost življenja bolnikov s presajeno ledvico. Pri slovenskih verzijah obeh vprašalnikov smo preverjali notranjo in retestno zanesljivost njunih lestvic. Konstruktno veljavnost smo preverili s korelacijami med posameznimi lestvicami obeh vprašalnikov. Glede na že objavljene študije pri bolnikih po presaditvi ledvice (Franke idr., 1999; Stavem in Ganss, 2006) smo pričakovali:

1. negativna in srednje visoka korelacijska koeficienta lestvic Omejene kognitivne zmožnosti in S presaditvijo povezan stres vprašalnika ESRD-SCL-TM z lestvico Duševno zdravje (SF-36v2 ${ }^{\circledR}$ ),

2. negativen in visok korelacijski koeficient med lestvico Omejena telesna zmogljivost (ESRD-SCL-TM) in lestvico Telesna bolečina $\left(\mathrm{SF}-36 \mathrm{v} 2^{\circledR}\right)$,

3. negativne in nizke korelacijske koeficiente lestvic Stranski učinki kortikosteroidov ter Poraščenost in spremembe dlesni vprašalnika ESRD-SCL-TM z vsemi lestvicami vprašalnika SF-36v2 ${ }^{\circledR}$.
Prav tako smo preverili povezanost lestvic obeh vprašalnikov s kliničnimi in demografskimi spremenljivkami. Objavljene validacijske raziskave vprašalnikov iz drugih držav (Barotfi idr., 2006; Franke idr., 1999; Mingardi idr., 1999; Ortega, Valdes, Rebollo in Ortega, 2007; Rebollo idr., 2000; Stavem in Ganss, 2006) so pokazale nekaj značilnih korelacij, ki pa so bile večinoma nizke $(r<0,40)$. Raziskave, ki so analizirale napovedno moč demografskih in zdravstvenih dejavnikov na kakovost življenja po presaditvi ledvice (Barotfi idr., 2006; Franke idr., 1999; Gentile idr., 2013; Rebollo idr., 2000) izpostavljajo med demografskimi spremenljivkami spol (moški poročajo o boljši kakovosti življenja), starost (telesni vidik s starostjo upada, duševni se ne spreminja ali blago narašča) ter zaposlitev in izobrazbo (višje izobraženi in zaposleni poročajo o boljši kakovosti življenja). Med zdravstvenimi spremenljivkami se z lestvicami telesnega vidika kakovosti življenja pozitivno povezuje oz. jo napoveduje vrednost hemoglobina, $\mathrm{z}$ lestvicami telesnega in duševnega vidika pa indikatorji ledvične funkcije (npr. kreatinin) (Barotfi idr., 2006; Franke idr., 1999; Gentile idr., 2013). Prisotnost sladkorne bolezni ter čas od presaditve sta v objavljenih študijah (Franke idr., 1999; Stavem in Ganss, 2006) neznačilno ali nizko korelirala $\mathrm{z}$ lestvicami z zdravjem povezane kakovosti življenja vprašalnikov $\mathrm{SF}-36 \mathrm{v} 2^{\circledR}$ in ESRD-SCL-TM.

\section{Metoda}

\section{Udeleženci}

V raziskavo smo vključili bolnike po presaditvi ledvice ne glede na čas od presaditve. Vključitveni kriterij je bil stabilno zdravstveno stanje brez akutne okužbe ali drugega akutnega zdravstvenega posega $\mathrm{v}$ zadnjih 14 dneh pred vključitvijo. Za sodelovanje smo prosili vse bolnike, ki so ustrezali vključitvenemu kriteriju in so imeli na štiri naključno izbrane dni junija 2014 zdravstveni kontrolni pregled v ambulanti za bolnike s presajeno ledvico v UKC Ljubljana. Bolniki so za sodelovanje $\mathrm{v}$ raziskavi podali podpisan prostovoljni obveščen pristanek. Od 63 naprošenih bolnikov jih je ob prvem merjenju sodelovalo 58, od slednjih je v drugem merjenju vprašalnike izpolnilo in vrnilo 55 bolnikov.

V vzorcu bolnikov je bilo 33 moških in 22 žensk. Razpon njihove starosti je bil od 23 do 78 let, s povprečno starostjo 54 let. Večina (34) je bila poročenih. Izobrazbena struktura vzorca kaže, da jih je imelo 20 končano poklicno šolo, 17 srednjo šolo in deset višjo ali visoko. Zaposlenih je bilo osem bolnikov, 38 je bilo upokojenih (redno ali invalidsko). Demografska struktura vzorca najbolj odstopa od splošne slovenske populacije v letu 2014 (Statistični urad Republike Slovenije, 2016) na področju zaposlitve, saj znaša delež upokojenih bolnikov v vzorcu $65 \%$, medtem ko je znašal ta v splošni populaciji $26 \%$. Visok delež upokojenih bolnikov je povezan tako $\mathrm{z}$ višjo povprečno starostjo v vzorcu bolnikov (54 let; slovenska populacija: 42 let) kot tudi s samimi posledicami zdravljenja kronične ledvične bolezni, kjer je značilno zgodnejše upokojevanje. V izobrazbeni strukturi je vzorec bolnikov po presaditvi ledvice povsem primerljiv na področju dosežene srednje (31 \%) ter višje in visoke izobrazbe 
(18 \% bolnikov) (Statistični urad Republike Slovenije, 2016). Je pa $\mathrm{v}$ vzorcu bolnikov manj ljudi $\mathrm{z}$ dokončano osnovno šolo (11\%) v primerjavi s splošno populacijo (22 \%) ter več $\mathrm{z}$ doseženo poklicno izobrazbo $(36 \%) \mathrm{v}$ primerjavi s splošno populacijo (28\%).

\section{Pripomočki}

SF-36v2 ${ }^{\circledR}$. V raziskavi smo uporabili vprašalnik SF-36v2 ${ }^{\circledR}$ (angl. Short Form-36, Second version), ki je najpogosteje uporabljen splošni večdimenzijski vprašalnik z zdravjem povezane kakovosti življenja in je standardiziran ter validiran v številnih državah in na različnih splošnih in kliničnih populacijah (gl. npr. Maruish, 2011). Meri dve komponenti z zdravjem povezane kakovosti življenja, telesno in duševno, ki vsaka vsebuje po štiri lestvice. Rezultati vprašalnika se prikažejo s pomočjo standardnih točk $(T)$, kjer pomenijo višji rezultati boljšo oceno kakovosti življenja. Slovensko verzijo vprašalnika smo kupili od uradnega založnika iz Združenih držav Amerike (OptumInsight), ki nadzoruje njegovo uporabo s podelitvijo licence. Čeprav podrobnejših podatkov o avtorjih prevoda ter merskih karakteristikah slovenske verzije vprašalnika od založnika nismo dobili, je založnik s potrdilom zagotovil, da je bil prevod narejen po ustreznih postopkih in s sodelovanjem strokovnjakov za jezik, kjer so uporabili tehnike za medkulturno adaptacijo in s čimer zagotavljajo, da prevod ustreza angleški verziji vprašalnika.

ESRD-SCL-TM. Drugi uporabljeni vprašalnik ESRDSCL-TM (angl. The End-Stage Renal Disease - Symptom Checklist - Transplantation Module) meri specifično kakovost življenja po presaditvi ledvice s poudarkom na telesnih simptomih, stranskih učinkih povezanih z imunosupresivno terapijo in znakih stresa po presaditvi ledvice (Franke idr., 1999). Vprašalnik je oblikovan kot kontrolni seznam, ki obsega 43 simptomov, za katere bolnik ocenjuje na 5stopenjski lestvici, do katere stopnje je trenutno zaradi njih obremenjen (od 0 - »prav nič ne obremenjuje« do 4 - »zelo močno obremenjuje«). Za vsako od šestih lestvic (Omejena telesna zmogljivost, Omejene kognitivne zmožnosti, Srčna in ledvična disfunkcija, Stranski učinki kortikosteroidov, Poraščenost in spremembe dlesni, S presaditvijo povezan stres) se izračuna povprečni rezultat na vseh postavkah. Nižji rezultati pomenijo manjšo obremenjenost $s$ težavami in $s$ tem boljšo oceno specifične $\mathrm{z}$ zdravjem povezane kakovosti življenja.

V slovenski jezik smo vprašalnik prevedli po standardnem postopku iz angleške verzije vprašalnika, ki so nam jo posredovali avtorji. Slovenski zdravnik in psiholog, ki tekoče govorita angleško, sta prevedla vprašalnik v slovenščino. Prevode smo primerjali in glede neskladij dosegli konsenz za enotne izraze. Popravljena prevoda sta druga dva zdravnika prevedla nazaj $\mathrm{v}$ angleščino. Za vsa odstopanja smo se posvetovali $\mathrm{z}$ avtorji vprašalnika, ki so nam posredovali tudi nemško verzijo vprašalnika, tako da smo za nejasnosti uspeli najti ustrezne izraze.

Pri bolnikih smo pridobili podatke o spolu, starosti, zakonskem stanu, izobrazbi in zaposlitvenem statusu. V analizo smo vključili tudi naslednje spremenljivke, ki opisujejo bolnikovo zdravstveno stanje izmerjeno na dan njegovega zdravstvenega pregleda, ko je izpolnil izbrana vprašalnika: koncentracija serumskega kreatinina $(\mu \mathrm{mol} / \mathrm{L})$, koncentracija hemoglobina (g/dL), število zdravil, ki jih jemlje, prisotnost sladkorne bolezni in čas od presaditve.

\section{Postopek}

Delo smo zasnovali kot pilotno presečno raziskavo z dvema anketiranjema udeležencev v 21-dnevnem obdobju. Bolniki so vprašalnike izpolnili dvakrat; prvič ob zdravstvenem pregledu v Centru za presaditev ledvic in drugič po 14-21 dneh, ko smo jim vprašalnike poslali na dom in so izpolnjene vrnili po pošti. Pri drugem merjenju nismo uporabili nobene oblike opomnikov. Vsi vključeni bolniki so podali obveščen pristanek za sodelovanje v raziskavi. Raziskavo je odobrila komisija RS za medicinsko etiko, štev. dokumenta: 52/11/12. Raziskava je bila sofinancirana s strani Javne agencije za raziskovalne projekte Republike Slovenije, št. projekta P30323.

Vse statistične analize so bile izvedene $\mathrm{z}$ uporabo statističnega paketa IBM SPSS Statistics 20.

\section{Rezultati}

$\mathrm{V}$ pilotni raziskavi so sodelovali bolniki, pri katerih je od presaditve ledvice minilo od enega meseca do 29 let, pri čemer je znašala mediana časa od presaditve 47 mesecev oz. skoraj štiri leta. Izmerjene vrednosti zdravstvenih indikatorjev so bile $\mathrm{v}$ vzorcu $\mathrm{v}$ pričakovanem razponu za bolnike po presaditvi ledvice in so znašale za hemoglobin od 95 do $166 \mathrm{~g} / \mathrm{dL}$ (mediana $130 \mathrm{~g} / \mathrm{dL}$ ) ter za kreatinin od 50 do $571 \mu \mathrm{mol} / \mathrm{L}$ (mediana $113 \mu \mathrm{mol} / \mathrm{L}$ ). Bolniki so jemali $\mathrm{v}$ času merjenja od pet do 19 različnih zdravil, kjer je znašala mediana 11. Dvanajst bolnikov se je sočasno zdravilo zaradi sladkorne bolezni.

\section{Rezultati preverjanja zanesljivosti}

V tabeli 1 so prikazane osnovne opisne statistike po posameznih lestvicah obeh vprašalnikov za merjenje $\mathrm{z}$ zdravjem povezane kakovosti življenja ter rezultati preverjanja zanesljivosti.

Višina izračunanih aritmetičnih sredin na vprašalniku SF-36v2 ${ }^{\circledR}$ kaže, da ocenjuje vzorec bolnikov po presaditvi ledvice svojo kakovost življenja kot dobro, če upoštevamo, da gre za standardizirane rezultate s sredino 50 in standardno deviacijo 10. Druga značilnost, ki jo opazimo pri dobljenih rezultatih na vprašalniku SF-36v2 ${ }^{\circledR}$ je, da so povprečne ocene bolnikov pri drugem merjenju na vseh lestvicah nekoliko nižje.

Izračuni rezultatov na vprašalniku ESRD-SCL-TM po posameznih lestvicah kažejo, da bolniki $\mathrm{v}$ povprečju niso pomembno obremenjeni $\mathrm{z}$ neželenimi učinki jemanja imunosupresivne terapije, saj se nahajajo aritmetične sredine dobljenih rezultatov pod vrednostjo ena, ki pomeni majhno obremenjenost.

Koeficienti notranje zanesljivosti alfa na obeh vprašalnikih in $\mathrm{v}$ obeh merjenjih se gibljejo od 0,66 do 0,96. Retestno zanesljivost smo ocenili $\mathrm{z}$ intraklasnim koeficientom 
Tabela 1. Opisne statistike rezultatov vprašalnikov SF-36v2 $2^{\circledR}$ in ESRD-SCL-TM ter koeficienti zanesljivosti

\begin{tabular}{|c|c|c|c|c|c|c|c|c|c|}
\hline \multirow{3}{*}{ SF-36v2 ${ }^{\circledR}$} & \multicolumn{4}{|c|}{ Prva meritev $(N=56)$} & \multicolumn{5}{|c|}{ Druga meritev $(N=50)$} \\
\hline & $\begin{array}{r}M \\
(S D) \\
\end{array}$ & $\begin{array}{l}\text { Min } \\
(\%)^{\mathrm{a}}\end{array}$ & $\begin{array}{l}\operatorname{Max} \\
(\%)^{\mathrm{a}}\end{array}$ & $\alpha$ & $\begin{array}{r}M \\
(S D) \\
\end{array}$ & $\begin{array}{l}\text { Min } \\
(\%)^{\mathrm{a}}\end{array}$ & $\begin{array}{l}\text { Max } \\
(\%)^{\mathrm{a}}\end{array}$ & $\alpha$ & $I K K$ \\
\hline & & & & & & & & & \\
\hline PF & $\begin{array}{r}80,15 \\
(20,09)\end{array}$ & $\begin{array}{l}15 \\
(2)\end{array}$ & $\begin{array}{l}100 \\
(20)\end{array}$ & 0,90 & $\begin{array}{r}77,32 \\
(22,33)\end{array}$ & $\begin{array}{r}0 \\
(2)\end{array}$ & $\begin{array}{l}100 \\
(14)\end{array}$ & 0,92 & 0,39 \\
\hline $\mathrm{RP}$ & $\begin{array}{r}72,51 \\
(25,52)\end{array}$ & $\begin{array}{l}6,3 \\
\text { (4) }\end{array}$ & $\begin{array}{l}100 \\
(23)\end{array}$ & 0,93 & $\begin{array}{r}68,56 \\
(26,74)\end{array}$ & $\begin{array}{l}6,3 \\
(2)\end{array}$ & $\begin{array}{l}100 \\
(20)\end{array}$ & 0,96 & 0,30 \\
\hline BP & $\begin{array}{r}69,32 \\
(28,09)\end{array}$ & $\begin{array}{r}0 \\
(2)\end{array}$ & $\begin{array}{l}100 \\
(30)\end{array}$ & 0,92 & $\begin{array}{r}66,92 \\
(27,39)\end{array}$ & $\begin{array}{r}0 \\
(2)\end{array}$ & $\begin{array}{l}100 \\
(26)\end{array}$ & 0,90 & 0,51 \\
\hline $\mathrm{GH}$ & $\begin{array}{r}59,27 \\
(18,86)\end{array}$ & $\begin{array}{l}10 \\
(2)\end{array}$ & $\begin{array}{l}97 \\
(4)\end{array}$ & 0,71 & $\begin{array}{r}55,72 \\
(19,17)\end{array}$ & $\begin{array}{l}20 \\
\text { (4) }\end{array}$ & $\begin{array}{l}97 \\
(2)\end{array}$ & 0,66 & 0,26 \\
\hline VT & $\begin{array}{r}69,31 \\
(18,40)\end{array}$ & $\begin{array}{r}18,7 \\
(2)\end{array}$ & $\begin{array}{r}100 \\
(5)\end{array}$ & 0,82 & $\begin{array}{r}69,62 \\
(18,70)\end{array}$ & $\begin{array}{l}31 \\
(6)\end{array}$ & $\begin{array}{r}100 \\
(4)\end{array}$ & 0,87 & 0,36 \\
\hline $\mathrm{SF}$ & $\begin{array}{r}79,24 \\
(23,87)\end{array}$ & $\begin{array}{l}25 \\
(7)\end{array}$ & $\begin{array}{l}100 \\
(39)\end{array}$ & 0,80 & $\begin{array}{r}77,28 \\
(26,93)\end{array}$ & $\begin{array}{r}0 \\
(2)\end{array}$ & $\begin{array}{l}100 \\
(44)\end{array}$ & 0,88 & 0,23 \\
\hline $\mathrm{RE}$ & $\begin{array}{r}80,36 \\
(23,81)\end{array}$ & $\begin{array}{l}8,3 \\
(2)\end{array}$ & $\begin{array}{l}100 \\
(41)\end{array}$ & 0,90 & $\begin{array}{r}77,94 \\
(22,78)\end{array}$ & $\begin{array}{l}25 \\
\text { (4) }\end{array}$ & $\begin{array}{l}100 \\
(12)\end{array}$ & 0,90 & 0,33 \\
\hline MH & $\begin{array}{r}80,13 \\
(13,84)\end{array}$ & $\begin{array}{l}40 \\
(2)\end{array}$ & $\begin{array}{l}100 \\
(11)\end{array}$ & 0,81 & $\begin{array}{r}79,30 \\
(16,44)\end{array}$ & $\begin{array}{l}40 \\
(4)\end{array}$ & $\begin{array}{l}100 \\
(12)\end{array}$ & 0,85 & 0,48 \\
\hline ESRD-SC & & & & & & & & & \\
\hline LPC & $\begin{array}{r}0,85 \\
(0,59)\end{array}$ & $\begin{array}{r}0 \\
(5)\end{array}$ & $\begin{array}{r}2,33 \\
(2)\end{array}$ & 0,80 & $\begin{array}{r}0,81 \\
(0,62)\end{array}$ & $\begin{array}{r}0 \\
(8)\end{array}$ & $\begin{array}{r}2,80 \\
(2)\end{array}$ & 0,87 & 0,74 \\
\hline LCC & $\begin{array}{r}0,86 \\
(0,52)\end{array}$ & $\begin{array}{r}0 \\
\text { (4) }\end{array}$ & $\begin{array}{r}2,25 \\
(2)\end{array}$ & 0,75 & $\begin{array}{r}0,76 \\
(0,51)\end{array}$ & $\begin{array}{r}0 \\
(6)\end{array}$ & $\begin{array}{r}2,00 \\
(2)\end{array}$ & 0,84 & 0,77 \\
\hline CRD & $\begin{array}{r}0,79 \\
(0,62)\end{array}$ & $\begin{array}{r}0 \\
(9)\end{array}$ & $\begin{array}{r}2,71 \\
(2)\end{array}$ & 0,79 & $\begin{array}{r}0,79 \\
(0,60)\end{array}$ & $\begin{array}{r}0 \\
(6)\end{array}$ & $\begin{array}{r}2,17 \\
(2)\end{array}$ & 0,76 & 0,90 \\
\hline SEC & $\begin{array}{r}0,86 \\
(0,72)\end{array}$ & $\begin{array}{r}0 \\
\text { (11) }\end{array}$ & $\begin{array}{r}3,60 \\
(2)\end{array}$ & 0,79 & $\begin{array}{r}0,79 \\
(0,78)\end{array}$ & $\begin{array}{r}0 \\
(20)\end{array}$ & $\begin{array}{r}3,60 \\
(2)\end{array}$ & 0,86 & 0,84 \\
\hline IGGH & $\begin{array}{r}0,43 \\
(0,48)\end{array}$ & $\begin{array}{r}0 \\
\text { (33) }\end{array}$ & $\begin{array}{r}1,80 \\
(2)\end{array}$ & 0,71 & $\begin{array}{r}0,66 \\
(0,46)\end{array}$ & $\begin{array}{r}0 \\
(38)\end{array}$ & $\begin{array}{r}2,00 \\
(4)\end{array}$ & 0,68 & 0,69 \\
\hline TPD & $\begin{array}{r}0,70 \\
(0,46)\end{array}$ & $\begin{array}{r}0 \\
(7)\end{array}$ & $\begin{array}{r}2,13 \\
(2)\end{array}$ & 0,71 & $\begin{array}{r}0,36 \\
(0,42)\end{array}$ & $\begin{array}{r}0 \\
(8)\end{array}$ & $\begin{array}{r}1,75 \\
(2)\end{array}$ & 0,78 & 0,73 \\
\hline
\end{tabular}

Opombe: PF - Telesna zmogljivost, RP - Omejitve telesne zmogljivosti, BP - Telesna bolečina, GH - Splošno zdravje, VT - Vitalnost, SF

- Socialno funkcioniranje, RE - Čustvene težave, MH - Duševno zdravje, LPC - Omejena telesna zmogljivost, LCC - Omejene kognitivne zmožnosti, CRD - Srčna in ledvična disfunkcija, SEC - Stranski učinki kortikosteroidov, IGGH - Poraščenost in spremembe dlesni, TPD S presaditvijo povezan stres.

$\alpha$ - koeficient notranje skladnosti alfa; IKK - intraklasni koeficient korelacije

${ }^{a}$ Odstotek bolnikov v vzorcu z dosežnim najnižjim ali najvišjim rezultatom (učinek stropa in tal)

korelacije. Ker nas je bolj kot klasična zanesljivost zanimala medsebojna primerljivost oz. izmenljivost dveh meritev, smo uporabili tip 2,1 za skladnost, ki je občutljiv na razlike $\mathrm{v}$ povprečnem dosežku na obeh meritvah.

Intraklasni koeficienti so sprejemljivo visoki na vprašalniku ESRD-SCL-TM, vendar pa so presenetljivo nizki za vprašalnik SF-36v2 ${ }^{\circledR}$. Zaradi na videz precejšnjih razlik v aritmetičnih sredinah na posameznih lestvicah vprašalnika SF-36v2 ${ }^{\circledR}$ med prvim in drugim merjenjem, smo dobljene razlike preverili s $t$-testom za odvisna vzorca, kjer smo sočasno uporabili metodo zankanja (angl. bootstrap), vendar nobena ni bila statistično značilna.

Ker ima lahko na višino koeficienta zanesljivosti pomemben vpliv porazdelitev samih rezultatov, prikazujemo
V tabeli 1 tudi vrednosti najnižjih ( $\min$ ) in najvišjih (max) rezultatov ter odstotek bolnikov, ki so te vrednosti dosegli (učinek stropa in tal). Iz prikazanih rezultatov je razvidno, da se pojavi učinek stropa, ki ga definiramo kot pomembnega, če več kot $15 \%$ vzorca doseže najvišji možni rezultat na lestvici (Terwee idr., 2007), v prvem merjenju na petih lestvicah (Telesna zmogljivost, Omejitve telesne zmogljivosti, Telesna bolečina, Socialno funkcioniranje in Čustvene težave), v drugem merjenju pa na treh lestvicah vprašalnika SF-36v2 ${ }^{\circledR}$ (Omejitve telesne zmogljivosti, Telesna bolečina, Socialno funkcioniranje). Vprašalnik SF-36v2 ${ }^{\circledR}$ na navedenih lestvicah slabše razlikuje med tistimi bolniki, ki ocenjujejo svojo z zdravjem povezano kakovost življenja kot visoko. O pomembnem učinku stropa na vprašalniku SF-36v ${ }^{\circledR}$ poročajo 
Tabela 2. Pearsonovi korelacijski koeficienti med lestvicami vprašalnikov SF-36v2 ${ }^{\circledR}$ (vrstice) in ESRD-SCL-TM (stolpci) ter intervali zaupanja izračunani z metodo zankanja $(N=50)$

\begin{tabular}{lrrrrrr}
\hline & LPC & LCC & CRD & SEC & IGGH & TPD \\
\hline PF &,$- 48^{* *}$ &,- 10 &,$- 27^{*}$ &,- 18 &,- 09 &,- 21 \\
& {$[-, 75 ;-, 22]$} & {$[-, 36 ;-, 16]$} & {$[-, 53 ;-, 07]$} & {$[-, 41 ;-, 09]$} & {$[-, 19 ;-, 32]$} & {$[-, 48 ;-, 07]$} \\
RP &,$- 56^{* *}$ &,$-- 34^{* *}$ &,$- 46^{* *}$ &,$- 36^{* *}$ &,- 11 &,$- 33^{*}$ \\
& {$[-, 77 ;-, 28]$} & {$[-, 60 ;-, 04]$} & {$[-, 70 ;-, 23]$} & {$[-, 62 ;-, 02]$} & {$[-, 43 ;-, 20]$} & {$[-, 60 ;-, 01]$} \\
BP &,$- 80^{* *}$ &,$- 32^{*}$ &,$- 52^{* *}$ &,$- 31^{*}$ &,$- 26^{*}$ &,$- 49^{* *}$ \\
& {$[-, 90 ;-, 64]$} & {$[-, 56 ;-, 04]$} & {$[-, 70 ;-, 32]$} & {$[-, 52 ;-, 06]$} & {$[-, 50 ;-, 02]$} & {$[-, 66 ;-, 30]$} \\
GH &,$- 58^{* *}$ &,,- 19 &,$- 36^{* *}$ &,- 20 &,- 05 &,$- 42^{* *}$ \\
& {$[-, 77 ;-, 33]$} & {$[-, 46 ;-, 06]$} & {$[-, 53 ;-, 21]$} & {$[-, 39 ;-, 01]$} & {$[-, 29 ;-, 18]$} & {$[-, 66 ;-, 20]$} \\
VT &,$- 77^{* *}$ &,,$- 39^{* *}$ &,$- 58^{* *}$ &,$- 35^{* *}$ &,$- 31^{*}$ &,$- 50^{* *}$ \\
& {$[-, 86 ;-, 64]$} & {$[-, 63 ;-, 05]$} & {$[-, 74 ;-, 38]$} & {$[-, 57 ;-, 03]$} & {$[-, 57 ;-, 03]$} & {$[-, 69 ;-, 26]$} \\
SF &,,$- 59^{* *}$ &,,$- 37^{* *}$ &,$- 61^{* *}$ &,$- 42^{* *}$ &,- 21 &,$- 50^{* *}$ \\
& {$[-, 79 ;-, 31]$} & {$[-, 63 ;-, 04]$} & {$[-, 79 ;-, 35]$} & {$[-, 63 ;-, 15]$} & {$[-, 51 ;-, 15]$} & {$[-, 70 ;-, 21]$} \\
RE &,$- 53^{* *}$ &,,$- 37^{* *}$ &,$- 47^{* *}$ &,$- 34^{* *}$ &,- 22 &,$- 53^{* *}$ \\
& {$[-, 73 ;-, 29]$} & {$[-, 61 ;-, 05]$} & {$[-, 73 ;-, 16]$} & {$[-, 59 ;-, 07]$} & {$[-, 55 ;-, 20]$} & {$[-, 76 ;-, 21]$} \\
MH &,$- 62^{* *}$ &,,$- 53^{* *}$ &,$-- 32^{*}$ &,$- 36^{* *}$ &,$- 46^{* *}$ &,$- 60^{* *}$ \\
& {$[-, 79 ;-, 38]$} & {$[-, 73 ;-, 25]$} & {$[-, 59 ;-, 05]$} & {$[-, 57 ;-, 02]$} & {$[-, 69 ;-, 12]$} & {$[-, 77 ;-, 38]$} \\
\hline
\end{tabular}

Opombe: PF - Telesna zmogljivost, RP - Omejitve telesne zmogljivosti, BP - Telesna bolečina, GH - Splošno zdravje, VT - Vitalnost, SF - Socialno funkcioniranje, RE - Čustvene težave, MH - Duševno zdravje, LPC - Omejena telesna zmogljivost, LCC - Omejene kognitivne zmožnosti, CRD - Srčna in ledvična disfunkcija, SEC - Stranski učinki kortikosteroidov, IGGH - Poraščenost in spremembe dlesni, TPD S presaditvijo povezan stres.

${ }^{*} p<0,05 ;{ }^{* *} p<0,01$

tudi založniki (Maruish, 2011) in drugi avtorji validacij vprašalnika na vzorcih ledvičnih bolnikov (Barotfi idr., 2006; Gomez-Besteiro, Santiago-Pérez, Alonso-Hernández, Valdés-Conedo in Rebollo-Alvarez, 2004; Stavem in Ganss, 2006).

\section{Rezultati preverjanja veljavnosti}

Konstruktno veljavnost smo preverili s korelacijami med lestvicami obeh uporabljenih vprašalnikov $\mathrm{v}$ prvem merjenju, ko so bili pogoji izpolnjevanja vprašalnikov za bolnike izenačeni.

Korelacije med lestvicami vprašalnikov SF-36v2 ${ }^{\circledR}$ in ESRD-SCL-TM kažejo smiselne povezave (tabela 2). Vsi korelacijski koeficienti so negativni, saj pomenijo višji rezultati na vprašalniku SF-36v2 ${ }^{\circledR}$ boljšo, na vprašalniku ESRD-SCL-TM pa slabše ocenjeno $\mathrm{z}$ zdravjem povezano kakovost življenja. Prav tako se dobljeni korelacijski koeficienti skladajo $\mathrm{z}$ rezultati drugih avtorjev, ki so pri merjenju z zdravjem povezane kakovosti življenja bolnikov po presaditvi ledvice sočasno uporabili oba izbrana vprašalnika (Franke idr., 1999; Stavem in Ganss, 2006):

1. $\mathrm{z}$ lestvico Duševno zdravje (SF-36v2 ${ }^{\circledR}$ ) sta negativno in srednje visoko korelirali lestvici vprašalnika ESRDSCL-TM Omejene kognitivne zmožnosti $(r=-0,53)$ in $\mathrm{S}$ presaditvijo povezan stres $(r=-0,60)$,

2. lestvica Omejena telesna zmogljivost (ESRD-SCL-TM) je negativno in visoko korelirala $\mathrm{z}$ lestvico Telesna bolečina na vprašalniku SF-36v $2^{\circledR}(r=-0,80)$,

3. med lestvicami vprašalnika SF-36v2 ${ }^{\circledR}$ in dvema lestvicama specifičnega vprašalnika ESRD-SCL-TM, ki merita stranske učinke imunosupresivnih zdravil (Stranski učinki kortikosteroidov, Poraščenost in spremembe dlesni), so korelacije večinoma nizke, saj merita slednji lestvici specifično simptomatiko po presaditvi ledvice.

Tudi rezultati povezanosti obeh vprašalnikov s kliničnimi in demografskimi spremenljivkami (tabela 3) so podobni tistim, o katerih poročajo nemški in norveški avtorji (Franke idr., 1999; Stavem in Ganss, 2006). Rezultati na lestvicah vprašalnikov z zdravjem povezane kakovosti življenja nizko korelirajo z demografskimi spremenljivkami $(r<0,36)$. Največ značilnih korelacij zasledimo med lestvicami kakovosti življenja in spolom, kjer so ženske ocenjevale svojo kakovost življenja na obeh uporabljenih vprašalnikih kot slabšo. Starost in zaposlitev se nista značilno povezovali z nobeno od lestvic, so pa korelacijski koeficienti z doseženo stopnjo izobrazbe pokazali značilno povezavo na dveh lestvicah vprašalnika ESRD-SCL-TM, kjer se višja stopnja izobrazbe povezuje z manjšo obremenjenostjo zaradi omejenih telesnih ali kognitivnih zmogljivosti.

$\mathrm{V}$ nadaljevanju smo preverili korelacije med lestvicami obeh vprašalnikov in kliničnimi (zdravstvenimi) spremenljivkami. Višina hemoglobina se pozitivno povezuje z višjo oceno na lestvici Splošnega zdravja in Vitalnosti. Kreatinin (indikator delovanja presajene ledvice) se značilno in negativno povezuje z oceno na lestvici Splošnega zdravja. Število zdravil, ki jih bolniki jemljejo po presaditvi, se značilno in negativno povezuje $\mathrm{z}$ ocenjeno Telesno zmogljivostjo in oceno Splošnega zdravja. Korelacije med lestvicami z zdravjem povezane kakovosti življenja ter časom od posega ter sladkorno boleznijo niso značilne. 
Tabela 3. Pearsonovi korelacijski koeficienti med lestvicami na vprašalniku SF-36v2 ${ }^{\circledR}$ in ESRD-SCL-TM ter demografskimi in zdravstvenimi spremenljivkami ter intervali zaupanja izračunani z metodo zankanja $(N=50)$

\begin{tabular}{|c|c|c|c|c|c|c|c|c|c|}
\hline & spol & starost & izobrazba & zaposlitev & $\begin{array}{r}\text { hemoglobin } \\
\mathrm{g} / \mathrm{dL}\end{array}$ & $\begin{array}{r}\text { kreatinin } \\
\mu \mathrm{mol} / \mathrm{L}\end{array}$ & $\begin{array}{l}\text { število } \\
\text { zdravil }\end{array}$ & $\begin{array}{l}\text { čas od } \\
\text { posega }\end{array}$ & $\begin{array}{r}\text { sladkorna } \\
\text { bolezen }\end{array}$ \\
\hline \multirow[t]{2}{*}{ PF } &,- 22 & & ,07 & ,08 &, 1 & 10 &,- 3 & &,- 06 \\
\hline & $47 ;, 05]$ & $33 ;, 19]$ & $-, 16 ;, 29]$ & $28 ;, 47]$ & $22 ;, 4$ &, $52 ;, 1$ & $49 ;-, 09]$ & $41 ;$ & $; 33 ;, 20]$ \\
\hline \multirow[t]{2}{*}{ RP } &,$- 36^{*}$ &,- 11 &, 07 &, 15 &, 27 &, 05 &,- 22 &, 06 &,- 01 \\
\hline & $, 59 ;-, 10]$ & {$[-, 38 ;, 18]$} & {$[-, 20 ;, 31]$} & {$[-, 14 ;, 44]$} & {$[-, 02 ;, 51]$} & {$[-, 22 ;, 20]$} & {$[-, 46 ;, 07]$} & {$[-, 28 ;, 35]$} & {$[-, 35 ;, 28]$} \\
\hline \multirow[t]{2}{*}{ BP } &,- 25 & & ,26 & ,22 & ,16 &, 02 &,- 14 & & ,13 \\
\hline & $0 ;, 02]$ & ;32;, 17$]$ & {$[-, 09 ;, 53]$} & {$[-, 07 ;, 48]$} & $13 ;, 42$ & -21;,, 1 & ,41; , 13] & $35 ;$ & {$[-, 14 ;, 36]$} \\
\hline \multirow[t]{2}{*}{ GH } &,- 23 &, 07 & ,16 &, 23 &, $32^{*}$ &,$- 29^{*}$ &,$- 30^{*}$ & &,- 09 \\
\hline & $8 ;, 06]$ & {$[-, 17 ;, 33$} & {$[-, 16 ;, 44]$} & {$[-, 06 ;, 50]$} & {$[, 09 ;, 52]$} & $-, 47 ;-, 19]$ & {$[-, 61 ;, 05]$} &,- 40 & {$[-, 36 ;, 18]$} \\
\hline \multirow[t]{2}{*}{ VT } &,- 26 &,- 03 &,- 03 &, 23 &, $35^{*}$ &, 00 &,- 17 &,- 01 &,- 02 \\
\hline & {$[-, 49 ;, 02]$} & {$[-, 25 ;, 22]$} & {$[-, 28 ;, 24]$} & {$[-, 13 ;, 56]$} & {$[, 12 ;, 55]$} & {$[-, 35 ;, 15]$} & {$[-, 41 ;, 13]$} & {$[-, 39 ;, 29]$} & {$[-, 29 ;, 22]$} \\
\hline \multirow[t]{2}{*}{$\mathrm{SF}$} &,- 16 &, 07 & , 10 &, 17 & & &,- 06 & &, 05 \\
\hline & $2 ;, 13]$ &, $18 ;, 32$ & {$[-, 17 ;, 35]$} & {$[-, 12 ;, 4$} & {$[-, 21 ;, 29$} & {$[-, 28 ;, 26$} & $, 31 ;, 22]$ & $37 ;$ & {$[-, 26 ;, 34]$} \\
\hline \multirow[t]{2}{*}{ RE } &,- 28 & ,09 & , 1 & & & &,- 20 & &,- 15 \\
\hline & {$[-, 54 ;, 01]$} & {$[-, 17 ;, 38]$} & {$[-, 07 ;, 43]$} & {$[-, 30 ;, 25]$} & {$[-, 02 ;, 47]$} & {$[-, 19 ;, 22]$} & {$[-, 45 ;, 06]$} & {$[-, 30 ;, 2]$} & {$[-, 47 ;, 19]$} \\
\hline \multirow[t]{2}{*}{ MH } &,- 14 &, 27 &, 15 &, 12 &, 21 &,- 12 &, 04 &,- 1 &,- 11 \\
\hline & $40 ;, 16]$ & 4. 527 & $, 11 ;, 39]$ & $, 15 ;, 40]$ & $07 ;, 45]$ & $-, 40 ;, 04]$ & $, 21 ;, 31]$ &,$- 48 ;, 16$ & {$[-, 39 ;, 20]$} \\
\hline \multirow[t]{2}{*}{ LPC } &, $35^{*}$ &, 09 &,$- 31^{*}$ & .03 &,- 28 & &, 16 & & \\
\hline & ; ,61] & 3. 391 & 0] & & & & $15 ;, 48]$ & J & $25 ;, 33]$ \\
\hline \multirow[t]{2}{*}{ LCC } &, $32^{*}$ &,- 01 &,$- 31^{*}$ & ,20 &,- 13 &,- 03 &, 02 &, 05 & ,10 \\
\hline & $03 ;, 57]$ & {$[-, 26 ;, 26]$} & {$[-, 59 ;-, 04]$} & {$[-, 11 ;, 45]$} & {$[-, 34 ;, 11]$} & {$[-, 19 ;, 31]$} & {$[-, 27 ;, 30]$} & {$[-, 25 ;, 34]$} & {$[-, 21 ;, 40]$} \\
\hline \multirow[t]{2}{*}{ CRD } &, 25 &, 09 &,- 08 &, 12 &,- 05 &,- 11 &, 25 &,- 10 &,- 04 \\
\hline & $6 ;, 55]$ & $, 24 ;, 35]$ & $-36 ;, 19$ & {$[-, 13 ;, 33]$} & 3. 2 & {$[-, 27 ;, 1$} & {$[-, 02 ;, 49]$} &,$- 35 ;, 2$ & {$[-, 29 ;, 24]$} \\
\hline \multirow[t]{2}{*}{ SEC } &, $37^{*}$ &,- 12 &,- 05 &, 05 &,- 12 &,- 01 &, 03 &,- 18 &,- 04 \\
\hline & ; 60] & {$[-, 39 ;, 12]$} & {$[-, 29 ;, 18]$} & {$[-, 22 ;, 28]$} & $35 ;, 13]$ & $-18 ;, 22]$ & {$[-, 22 ;, 28]$} & {$[-, 42 ;, 08]$} & {$[-, 26 ;, 25]$} \\
\hline \multirow[t]{2}{*}{ IGGH } &, $33^{*}$ &, 03 &,- 16 &, 06 &,- 10 &,- 16 &,- 12 &, 06 &,- 18 \\
\hline & $5 ;, 58]$ & {$[-, 27 ;, 30]$} & {$[-, 37 ;, 10]$} & {$[-, 24 ;, 34]$} & {$[-, 37 ;, 19]$} & {$[-, 30 ;, 16]$} & {$[-, 36 ;, 14]$} & $-, 24 ;, 37]$ & {$[-, 44 ;, 13]$} \\
\hline \multirow[t]{2}{*}{ TPD } &, $36^{*}$ &,- 07 &,- 25 &, 13 &,- 21 & &, 12 & & \\
\hline & {$[08 ;, 56]$} & {$[-, 34 ;, 26]$} & {$[-, 56 ;, 01$} & {$[-, 10 ;, 34]$} & & {$[-, 18 ;, 31]$} & {$[-, 13 ;, 39]$} & 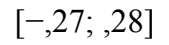 & {$[-, 33 ;, 33]$} \\
\hline
\end{tabular}

Opombe: PF - Telesna zmogljivost, RP - Omejitve telesne zmogljivosti, BP - Telesna bolečina, GH - Splošno zdravje, VT - Vitalnost, SF - Socialno funkcioniranje, RE - Čustvene težave, MH - Duševno zdravje, LPC - Omejena telesna zmogljivost, LCC - Omejene kognitivne zmožnosti, CRD - Srčna in ledvična disfunkcija, SEC - Stranski učinki kortikosteroidov, IGGH - Poraščenost in spremembe dlesni, TPD $S$ presaditvijo povezan stres. ${ }^{*} p<0,05$

\section{Razprava}

Namen pilotne raziskave na vzorcu bolnikov po presaditvi ledvice je bil ugotoviti merske lastnosti izbranih vprašalnikov z zdravjem povezane kakovosti življenja. Za izbor vprašalnikov SF-36v2 ${ }^{\circledR}$ in ESRD-SCL-TM smo se odločili po priporočilih preglednih študij (Avramovic in Stefanovic, 2012; Glover idr., 2011; Revicki idr., 2001), kjer prevladuje mnenje, da je za merjenje z zdravjem povezane kakovosti življenja pri bolnikih po presaditvi ledvice optimalno uporabiti kombinacijo splošnega in specifičnega vprašalnika. Medtem ko vprašalnik SF-36v $2^{\circledR}$ že obstaja v slovenski verziji, smo ESRD-SCL-TM po priporočenem postopku prevedli $\mathrm{v}$ slovenščino in prvič uporabili na izbrani skupini bolnikov.

Zanesljivost vprašalnikov smo preverjali $\mathrm{z}$ dvema koeficientoma, in sicer s koeficientom notranje zanesljivosti alfa in s koeficientom intraklasne korelacije za izračun zanesljivosti $\mathrm{v}$ času. Koeficienti notranje zanesljivosti alfa znašajo na našem vzorcu za vprašalnik SF-36v2 ${ }^{\circledR} \mathrm{v}$ obeh merjenjih od 0,71 do 0,96, z izjemo lestvice Splošno zdravje, kjer je znašal koeficient alfa $\mathrm{v}$ drugem merjenju 0,66. Avtorji vprašalnika (Maruish, 2011) navajajo pri preverjanju zanesljivosti vprašalnika na vzorcu splošne populacije $\mathrm{v}$ ZDA visoke koeficiente notranje zanesljivosti posameznih lestvic, ki se gibljejo med 0,82 in 0,96 . Koeficiente notranje skladnosti, ki so na vseh lestvicah vprašalnika presegli vrednost 0,70 , navajajo tudi $\mathrm{v}$ validacijskih raziskavah vprašalnika na splošnih populacijah v drugih državah, kot npr. na Nizozemskem (Aaronson idr., 1998), Danskem (Bjorner, Damsgaard, Watt in Goenvold, 1998), Japonskem (Fukuhara, Bito, Green, Hsiao in Kurokawa, 1998) ter na Hrvaškem (Maslić Seršić in Vuletić, 2006). Ob pregledu validacijskih študij vprašalnika SF-36v2 ${ }^{\circledR}$ pri ledvičnih bolnikih v drugih državah (Gómez-Besteiro idr., 2004; Mingardi idr., 1999) ugotavljamo, da je enako kot pri našem vzorcu tudi pri njih koeficient notranje zanesljivosti na lestvici Splošnega zdravja najnižji (v obeh referencah znaša 0,70), iz česar sklepamo, da gre najverjetneje za značilnost lestvice. Za natančnejšo razjasnitev opisanega smo dodatno preverili korelacije med (petimi) postavkami in skupnim rezultatom na lestvici. Pri 
štirih postavkah se korelacijski koeficienti nahajajo $\mathrm{v}$ razponu od 0,44 do 0,62 , medtem ko znaša korelacija s peto postavko le 0,21. Gre za postavko, kjer bolniki ocenjujejo stopnjo strinjanja s trditvijo, da pričakujejo, da se jim bo zdravje poslabšalo. Ni presenetljivo, da ta postavka med ostalimi lestvicami vprašalnika SF-36v2 ${ }^{\circledR}$ najvišje korelira z lestvico Duševno zdravje $(r=0,43)$, saj se vsebinsko bolj nanaša na pričakovanja za prihodnost in s tem na morebitne strahove ob zdravljenju s presajeno ledvico, kot na oceno trenutnega splošnega zdravja, ki je osrednji predmet ocenjevanja lestvice Splošno zdravje. Rezultati zato nakazujejo potrebo po izključitvi oz. zamenjavi te postavke v lestvici Splošno zdravje.

Nemški avtorji za bolezen specifičnega vprašalnika kakovosti življenja ESRD-SCL-TM navajajo v svoji študiji visoko notranjo zanesljivost posameznih lestvic. Njihovi koeficienti notranje zanesljivosti alfa so se gibali med vrednostmi 0,76 in 0,85 (Franke idr., 1999). Koeficienti notranje zanesljivosti pri vprašalniku ESRD-SCL-TM so na vseh lestvicah našega vzorca v prvem merjenju višji od 0,71 . Pri tem vprašalniku odstopa $\mathrm{v}$ drugem merjenju koeficient zanesljivosti na lestvici Poraščenost in spremembe dlesni, ki znaša 0,68 . Glede na ostale koeficiente $v$ vprašalniku in edino opisano odstopanje menimo, da ne gre za pomembno omejitev pri uporabi vprašalnika $\mathrm{v}$ populacijski študiji, ki jo načrtujemo, bomo pa takrat ponovno preverili notranjo zanesljivost vseh lestvic.

Za preverjanje zanesljivosti v času smo uporabili koeficient intraklasne korelacije, ki meri, kako skladni so rezultati dveh merjenj.

Lestvice vprašalnika ESRD-SCL-TM so pokazale ustrezno zanesljivost $\mathrm{v}$ času, kar sklepamo iz dobljenih intraklasnih koeficientov, ki so višji od 0,69.

Vrednosti intraklasnih koeficientov na vprašalniku SF$36 \mathrm{v} 2^{\circledR}$ so $\mathrm{v}$ primerjavi z drugimi objavljenimi študijami, tako v splošni kot pri klinični populaciji (Marn-Vukadinović in Jamnik, 2011; Maruish, 2011), presenetljivo nizke. Na višino (intraklasnih in drugih) koeficientov zanesljivosti lahko vplivajo razlike med prvim in drugim merjenjem ali pa omejenost variabilnosti dosežkov, ki nastane med drugim kot posledica učinka stropa ali tal. V primeru slovenske oblike SF-36v $2^{\circledR}$ je bil pri nekaterih lestvicah prisoten izrazit učinek stropa. Na lestvicah Omejitve telesne zmogljivosti in Telesna bolečina je v obeh meritvah vsaj $20 \%$ bolnikov doseglo najvišji možni dosežek, na lestvici Socialno funkcioniranje pa celo $40 \%$ ali več. O učinku stropa poročajo v validacijskih študijah vprašalnika SF-36v $2^{\circledR}$ tudi drugi avtorji, ki so merili z zdravjem povezano kakovost življenja ledvičnih bolnikov po presaditvi (Barotfi idr., 2006; Gómez-Besteiro idr., 2004; Stavem in Ganss, 2006). Menimo, da je opisan učinek eden od možnih dejavnikov nizke variabilnosti naših rezultatov ter s tem nizkih vrednosti intraklasnih koeficientov. Dobljeni rezultati kažejo, da je kakovost življenja, ki jo meri SF-36v2 ${ }^{\circledR}$ na našem pilotnem vzorcu, manj stabilna spremenljivka. Ker je slednje glede na konstrukt merjenja in razmik dveh meritev pri stabilnih bolnikih v zgolj 14-21 dneh nepričakovano, in ker se naši rezultati ne skladajo $\mathrm{z}$ rezultati re-testne zanesljivosti vprašalnika SF-36v2 ${ }^{\circledR}$ v splošni populaciji (Maruish, 2011) ali pri ledvičnih bolnikih na večjih vzorcih (GómezBesteiro idr., 2004; Mingardi idr., 1999), velja razmisliti tudi o možnem vplivu neizenačenih pogojev merjenja $\mathrm{v}$ prvi in drugi meritvi. Čeprav med rezultati v prvem (čakalnica) in drugem merjenju (doma) nismo potrdili statistično značilnih razlik v aritmetičnih sredinah, so bolniki v drugem merjenju ocenjevali svojo z zdravjem povezano kakovost življenja kot slabšo. Možno je, da podajajo bolniki pri izpolnjevanju vprašalnikov $\mathrm{v}$ čakalnici višje ocene zaradi težnje po prikazovanju v ugodnejši luči. Slednje lahko izhaja iz manjše zasebnosti, ki jo imajo pri tem na voljo v čakalnici, ali iz občutka, da morajo pred zdravstvenimi delavci, ki so jim izročili v izpolnjevanje vprašalnik o kakovosti življenja, kljub zagotovljeni anonimnosti, poudariti svoje zadovoljstvo z izbranim načinom zdravljenja. Drugi možen vzrok je, da je $\mathrm{k}$ podajanju višjih in manj diferenciranih ocen (učinek stropa na lestvicah SF-36v2 ${ }^{\circledR}$ in učinek tal na lestvicah ESRD-SCLTM) prispevala negotovost bolnikov glede zdravstvenega stanja in delovanja presajene ledvice $\mathrm{v}$ času čakanja na zdravstveni pregled, ki jo glede na klinične izkušnje bolniki v največji meri doživljajo prav na dan pregleda. Pri načrtovanju glavne študije velja zato posebej razmisliti o najprimernejšem načinu in okoliščinah merjenja z zdravjem povezane kakovosti življenja za pridobitev zanesljivih rezultatov. Rezultati nakazujejo, da je vprašalnik SF-36v2 ${ }^{\circledR}$ za nadaljnjo uporabo pri bolnikih po presaditvi ledvice ustrezno notranje zanesljiv, zaradi nizkih intraklasnih korelacij pa je priporočljivo njegove rezultate interpretirati le znotraj določene časovne točke oz. merske situacije.

Konstruktno veljavnost smo preverjali s korelacijami med obema vprašalnikoma. Pri tem smo glede na pretekle raziskave (Franke idr., 1999; Ortega idr., 2007; Stavem in Ganss, 2006) in vsebino postavk preverili nekaj hipotez, ki jih predlagajo isti avtorji.

Lestvica Duševno zdravje (SF-36v2 ${ }^{\circledR}$ ) je po pričakovanjih negativno in srednje visoko korelirala $\mathrm{z}$ lestvicama Omejene kognitivne zmožnosti in $\mathrm{S}$ presaditvijo povezan stres vprašalnika ESRD-SCL-TM. Gre za tri lestvice, ki merijo duševni vidik doživljanja kakovosti življenja in obsegajo splošne duševne težave (npr. negotovost, napetost, tesnoba, slabo razpoloženje), doživljanje težav na področju kognitivnih zmožnosti (npr. slaba miselna pozornost, težave s spominom) ter s presaditvijo povezana negativna doživljanja (npr. negotovost glede delovanja presajene ledvice, strah pred odpovedjo presajenega organa).

Lestvica Omejena telesna zmogljivost (ESRD-SCL-TM) je visoko in negativno korelirala $\mathrm{z}$ lestvico Telesna bolečina vprašalnika SF-36v2 ${ }^{\circledR}(r=-0,80)$. Opisana visoka povezava je pričakovana, saj se vsebinsko obe lestvici osredotočata na doživljanje bolečine. Ta na lestvici vprašalnika SF-36v2 ${ }^{\circledR}$ ni specifično opredeljena, ampak se nanaša na doživljanje katerekoli bolečine, ki vpliva na omejitve v vsakodnevnem funkcioniranju bolnikov. Postavke na lestvici Omejena telesna zmogljivost (ESRD-SCL-TM) pa merijo na šestih od skupaj desetih postavk prav občutek obremenjenosti zaradi doživljanja specifičnih bolečin (npr. v kosteh, sklepih, mišicah), kar so znani neželeni učinki imunosupresivne terapije pri zdravljenju po presaditvi ledvice (Valderrábano, Jofre in López-Gómez, 2001).

Med lestvicami vprašalnika SF-36v2 ${ }^{\circledR}$ in dvema lestvicama vprašalnika ESRD-SCL-TM, ki merita stranske učinke imunosupresivnih zdravil (Stranski učinki kortikosteroidov, 
Poraščenost in spremembe dlesni), so korelacije na večini lestvic med nižjimi $(r<0,40)$, saj gre za specifično simptomatiko po presaditvi ledvice. Lestvica Stranski učinki kortikosteroidov meri občutke obremenjenosti zaradi videza, ki je ob jemanju nekaterih imunosupresivnih zdravil lahko pri bolnikih spremenjen in se kaže kot zabuhlost obraza. Druga lestvica (Poraščenost in spremembe dlesni) meri občutke obremenjenosti zaradi večje poraščenosti in sprememb dlesni (krvavenje, otekline). Višina korelacijskih koeficientov (tabela 2) omenjenih lestvic kaže še, da lestvici višje korelirata $\mathrm{z}$ lestvicama Duševno zdravje $(r=-0,46)$ in Socialno funkcioniranje $(r=-0,42)$ vprašalnika SF-36v $2^{\circledR}$. Doživljanje večje obremenjenosti zaradi neželenih vizualnih učinkov imunosupresivne terapije po presaditvi ledvice se nekoliko višje povezuje s slabšo kakovostjo življenja na duševnem kot na telesnem področju.

Dobljeni korelacijski koeficienti povezanosti med lestvicami splošnega in specifičnega vprašalnika z zdravjem povezane kakovosti življenja tako potrjujejo postavljene hipoteze in se večinoma skladajo z rezultati, ki jih navajajo tudi drugi avtorji (Franke idr., 1999; Stavem in Ganss, 2006), velja pa $\mathrm{v}$ glavni študiji $\mathrm{z}$ zdravjem povezane kakovosti življenja slovenskih bolnikov po presaditvi ledvice preveriti ponovljivost dobljenih rezultatov.

Rezultati v tabeli 3 kažejo tudi na vzorcu slovenskih bolnikov po presaditvi ledvice podobne povezave med $\mathrm{Z}$ zdravjem povezano kakovostjo življenja ter demografskimi in kliničnimi spremenljivkami, o kakršnih poročajo drugi raziskovalci (Barotfi idr., 2006; Franke idr., 1999; Gentile idr., 2013; Rebollo idr., 2000; Stavem in Ganss, 2006). Rezultati na lestvicah vprašalnikov z zdravjem povezane kakovosti življenja nizko korelirajo $\mathrm{z}$ demografskimi značilnostmi $(r<$ 0,36). Največ značilnih korelacij zasledimo med lestvicami uporabljenih vprašalnikov in spolom, kjer so ženske ocenjevale svojo kakovost življenja na obeh uporabljenih vprašalnikih kot slabšo. Povezava s spolom se kot značilnejša pokaže na lestvicah vprašalnika ESRD-SCL-TM, kjer pet od šestih koeficientov značilnih, medtem ko to velja za eno lestvico (Omejitve telesne zmogljivosti) na vprašalniku SF-36v2 ${ }^{\circledR}$. Spol se je sicer v številnih raziskavah izkazal za pomemben napovedni dejavnik $\mathrm{z}$ zdravjem povezane kakovosti življenja bolnikov in gre v korist moškim (Gentile idr., 2013; Valderrabano, Jofre in López-Gómez, 2001).

Starost se ni statistično značilno povezovala z nobeno od lestvic, nakazujejo pa predznaki korelacijskih koeficientov smer povezanosti, o kateri poročajo tudi drugi avtorji (Barofti idr., 2006; Rebollo idr., 2000). S starostjo telesni vidik z zdravjem povezane kakovosti življenja upada, medtem ko se duševni ne spreminja oz. lahko celo narašča.

Korelacijski koeficienti med $\mathrm{Z}$ zdravjem povezano kakovostjo življenja in zaposlitvijo niso značilni, čeprav je to ena od spremenljivk, ki se je pri drugih avtorjih na več lestvicah izkazala za tako (Franke idr., 1999; Stavem in Ganss, 2006). Domnevamo, da je k odsotnosti značilnih povezav med zaposlitvijo in lestvicami z zdravjem povezane kakovosti prispeval nizek delež zaposlenih bolnikov v našem vzorcu, saj je teh zgolj osem.

Izobrazba se je značilno povezovala $\mathrm{z}$ dvema lestvicama vprašalnika ESRD-SCL-TM, ki se nanašata na manjšo obremenjenostjo zaradi telesnih in kognitivnih zmogljivosti.
V nadaljevanju smo preverili ali se rezultati posameznih lestvic $\mathrm{z}$ zdravjem povezane kakovosti življenja smiselno povezujejo $\mathrm{z}$ izmerjenimi indikatorji zdravstvenega stanja bolnikov po presaditvi ledvice. Podobno kot poročajo drugi (Barofti idr., 2006; Franke idr., 1999; Rebollo idr., 2000; Stavem in Ganss, 2006), so tudi naše korelacije večinoma nizke.

Višji hemoglobin se pozitivno povezuje $z$ višjo oceno na lestvici Splošnega zdravja in Vitalnosti (SF-36v2 ${ }^{\circledR}$ ). Bolniki, ki niso slabokrvni, izražajo večje zadovoljstvo s kakovostjo življenja na področju ocene Splošnega zdravja in občutka vitalnosti (zmožnosti, da opravijo vsakodnevne naloge), kar je pričakovano, saj hemoglobin prispeva k boljši telesni zmogljivosti in manjši utrujenosti.

Kreatinin (indikator delovanja presajene ledvice) se negativno povezuje z oceno Splošnega zdravja. Če vemo, da so tipični simptomi napredovanja ledvične bolezni (višji kreatinin) utrujenost, nemoč, pomanjkanje energije in slabost (Kveder, 2014), je povezava $\mathrm{z}$ lestvico Splošnega zdravja na vprašalniku SF-36v $2^{\circledR}$ pričakovana.

Število zdravil, ki jih bolniki jemljejo po presaditvi, se značilno in negativno povezuje $\mathrm{z}$ ocenjeno Telesno zmogljivostjo in oceno Splošnega zdravja (SF-36v2 $\left.{ }^{\circledR}\right)$. Bolniki, ki jemljejo po presaditvi večje število zdravil, ocenjujejo $\mathrm{z}$ zdravjem povezano kakovost življenja kot slabšo predvsem na telesnem področju. Opisano razumemo v luči pridruženih telesnih bolezni, ki jih bolniki z več predpisanimi zdravili sočasno zdravijo po presaditvi ledvice.

Enako kot poročajo drugi (Barofti idr., 2006; Franke idr., 1999; Rebollo idr., 2000; Stavem in Ganss, 2006) so povezave med lestvicami z zdravjem povezane kakovosti življenja ter časom od posega ter sladkorno boleznijo tudi v našem vzorcu neznačilne. Doživljanje z zdravjem povezane kakovosti življenja se s časom od posega ali ob sočasnem zdravljenju sladkorne bolezni v našem vzorcu ne spreminja značilno.

Če povzamemo povezave med rezultati na lestvicah vprašalnikov z zdravjem povezane kakovosti življenja in demografskimi ter zdravstvenimi spremenljivkami, bi kljub pričakovanim nizkim korelacijam veljalo dodatno izpostaviti, da kaže za bolezen specifični vprašalnik (ESRD-SCL-TM) več povezav med merjenimi konstrukti in demografskimi spremenljivkami, medtem ko kaže splošni vprašalnik z zdravjem povezane kakovosti življenja (SF-36v2 ${ }^{\circledR}$ ) več povezav $\mathrm{z}$ indikatorji zdravstvenega stanja bolnikov po presaditvi ledvice.

V pilotni študiji preverjanja merskih značilnosti splošnega in specifičnega vprašalnika za merjenje z zdravjem povezane kakovosti življenja pri bolnikih po presaditvi ledvice ugotavljamo, da sta izbrana vprašalnika primerna za nadaljevanje raziskave na populaciji bolnikov po presaditvi ledvice. Prav tako ugotavljamo, da izkazuje slovenska verzija vprašalnika ESRD-SCL-TM, ki meri specifične vidike $\mathrm{z}$ zdravjem povezane kakovosti življenja, povezane $\mathrm{z}$ negativnimi dejavniki po presaditvi ledvice (stranski učinki zdravil, s presaditvijo povezan stres), smiselne povezave $\mathrm{z}$ vprašalnikom SF-36v2 ${ }^{\circledR}$. Se je pa slednji izkazal kot manj zanesljiv v času oz. v različnih merskih situacijah.

Omejitve opravljene študije so, da je bil vzorec relativno majhen in raznolik glede na demografske in zdravstvene spremenljivke ter da sta bila pogoja merjenja $\mathrm{z}$ vidika vpliva 
zunanjih dejavnikov na ocenjevanje $\mathrm{z}$ zdravjem povezane kakovosti življenja neizenačena zaradi različnega kraja izpolnjevanja vprašalnikov (prvič v čakalnici ambulante pred zdravstvenim pregledom, drugič doma). Slednje je potrebno pri načrtovanju glavne raziskave ustrezno načrtovati in za pridobitev zanesljivih podatkov bolnikom zagotoviti zasebnost pri izpolnjevanju vprašalnikov.

\section{Literatura}

Aaronson, N. K., Muller, M., Cohen, P. D. A., Essink-Bot, M. L., Fekkes, M., Sanderman, R., ... Verrips, E. (1998). Translation, validation, and norming of the Dutch language version of the SF-36SF-36v2 Health Survey in community and chronic disease populations. Journal of Clinical Epidemiology, 51(11), 1055-1068.

Avramovic, M. in Stefanovic, V. (2012). Health-related quality of life in different stages of renal failure. Artificial Organs, 36(7), 581-589.

Barotfi, S., Molnar, M.Z., Almasi, C., Kovacs, A. Z., Remport, A., Szeifert, L., ... Mucsi, I. (2006). Validation of the kidney disease quality of life-Short Form questionnaire in kidney transplant patients. Journal of Psychosomatic Research, 60(5), 495-504.

Bjorner, J. B., Damsgaard, M. T., Watt, T. in Groenvold, M. (1998). Tests of data quality, scaling assumptions, and reliability of the Danish SF-36. Journal of Clinical Epidemiology, 51(11), 1001-1011.

Bottomley, A., Jones, D. in Claassens, L. (2009). Patientreported outcomes: Assessment and current perspectives of the guidelines of the Food and Drug Administration and the reflection paper of the European Medicines Agency. European Journal of Cancer, 45(3), 347-353.

Bregant, T., Neubauer, D. in Derganc, M. (2012). Kakovost življenja mladostnikov, ki so $\mathrm{v}$ obdobju novorojenčka utrpeli hipoksično-ishemično encefalopatijo [Quality of life in adolescents followed after neonatal hypoxicishaemic encephalopathy]. Zdravniški vestnik, 81(5), 383-392.

Brejc, T. (2006). Vpliv zaznav zdravja in zloma kolka na strategije obvladovalnega vedenja starih rehabilitandov [Effects of illness and hip fracture perceptions on coping strategies of elderly rehabilitation clients]. Psihološka obzorja, 15(2), 67-88.

Danovitch, G. M. (2010). Options for patients with end-stage renal disease. V G. Danovitch (ur.), Handbook of Kidney Transplantation (5. izd., str. 1-18). Philadelphia, PA, ZDA: Lippincott Williams \& Wilkins.

Fiebiger, W., Mitterbauer, C. in Oberbauer, R. (2004). Health-related quality of life outcomes after kidney transplantation. Health and Quality of Life Outcomes, 2, 2.

Finkelstein, F. O., Wuerth, D. in Finkelstein, S. H. (2009). Health related quality of life and the CKD patient: Challenges for the nephrology community. Kidney International, 76(9), 946-952.
Franke, G. H., Reimer, J., Kohnle, M., Luetkes, P., Maehner, N. in Heemann, U. (1999). Quality of life in end-stage renal disease patients after successful kidney transplantation: Development of the ESRD symptom checklist Transplantation module. Nephron, 83(1), 31-39.

Fukuhara, S., Bito, S., Green, J., Hsiao, A. in Kurokawa, K. (1998). Translation, adaptation, and validation of the SF36 Health Survey for use in Japan. Journal of Clinical Epidemiology, 51(11), 1037-1044.

Gentile, S., Beauger, D., Speyer, E., Jouve, E., Dussol, B., Jacquelinet, C. in Briançon, S. (2013). Factors associated with health-related quality of life in renal transplant recipients: Results of a national survey in France. Health and Quality of Life Outcomes, 11(1), 88.

Glover, C., Banks, P., Carson, A., Martin, C.R. in Duffy, T. (2011). Understanding and assessing the impact of endstage renal disease on quality of life: A systematic review of the content validity of self-administered instruments used to assess health-related quality of life in end-stage renal disease. Patient, 4(1), 19-30.

Gómez-Besteiro, M. I., Santiago-Pérez, M. I., AlonsoHernández, Á., Valdés-Conedo, F. in Rebollo-Alvarez, P. (2004). Validity and reliability of the SF-36 questionnaire in patients on the waiting list for a kidney transplant and transplant patients. American Journal of Nephrology, 24, 346-351.

Hays, R. D., Kallich, J. D., Mapes, D. L., Coons, S. J. in Carter, W. B. (1994). Development of The Kidney Disease Quality of Life (KDQOL) instrument. Quality of Life Research: An International Journal of Quality of Life Aspects of Treatment, Care and Rehabilitation, 3(5), 329-338.

Keown, P. (2001). Improving quality of life - the new target for transplantation. Transplantation, 72(12 Suppl), S67-74.

Kveder, R. (2014). Pristop k bolniku z ledvično boleznijo [Approaching patients with a kidney disease]. V J. Lindič, D. Kovač, R. Kveder, M. Malovrh, J. Pajek, A. Aleš Rigler in A. Škoberne (ur.), Bolezni ledvic [Kidney disease] (str. 21-27). Ljubljana, Slovenija: Slovensko zdravniško društvo; Slovensko nefrološko društvo; Univerzitetni klinični center Ljubljana, Klinični oddelek za nefrologijo.

Laupacis, A., Pus, N., Muirhead, N., Wong, C., Ferguson, B. in Keown, P. (1993). Disease-specific questionnaire for patients with a renal transplant. Nephron, 64(2), 226-231.

Logar, B. (2005). Psihosocialni vidiki transplantacije ledvic [Psychosocial aspects of renal transplantation]. V A. Kandus, J. Buturović-Ponikvar in A. Bren (ur.), Presaditev Ledvic [Renal transplantation] (str. 149-155). Ljubljana, Slovenija: Klinični center Ljubljana, Klinični oddelek za nefrologijo.

Marn-Vukadinović, D. in Jamnik, H. (2011). Validation of the short form-36 health survey supported with isokinetic strength testing after sport knee injury. Journal of Sport Rehabilitation, 20(3), 261-276. 
Maslić Sersić, D. in Vuletić, G. (2006). Psychometric evaluation and establishing norms of Croatian SF-36 health survey: Framework for subjective health research. Croatian Medical Journal, 47(1), 95-102.

Maruish, M. (2011). User's manual for the SF-36 Health Survey (3rd ed.). Lincoln, RI, ZDA: QualityMetric.

Mingardi, G., Cornalba, L., Cortinovis, E., Ruggiata, R., Mosconi, P. in Apolone, G. (1999). Health-related quality of life in dialysis patients: A report from an Italian study using the SF-36 Health Survey: DIA-QOL Group. Nephrology, Dialysis, Transplantation, 14, 1503-1510.

Ortega, T., Valdés, C., Rebollo, P. in Ortega, F. (2007). Evaluation of reliability and validity of Spanish version of the end-stage renal disease symptom checklisttransplantation module. Transplantation, 84(11), 1428-1435.

Painter, P., Krasnoff, J. B., Kuskowski, M., Frassetto, L. in Johansen, K. (2012). Effects of modality change on health-related quality of life. Hemodialysis International: International Symposium on Home Hemodialysis, 16(3), 377-386.

Parfrey, P. S., Vavasour, H., Bullock, M., Henry, S., Harnett, J. D. in Gault, M. H. (1989). Development of a health questionnaire specific for end-stage renal disease. Nephron, 52(1), 20-28.

Rainer, J. P., Thompson, C. H. in Lambros, H. (2010). Psychological and psychosocial aspects of the solid organ transplant experience: A practice review. Psychotherapy, 47(3), 403-412.

Rebollo, P., Ortega, F., Baltar, J. M., Badia, X., AlvarezUde, F., Diaz-Corte, C., ... Alvarez-Grande, J. (2000). Health related quality of life (HRQOL) of kidney transplanted patients: Variables that influence it. Clinical Transplantation, 14(3), 199-207.

Revicki, D. A., Osoba, D., Fairclough, D., Barofsky, I., Berzon, R., Leidy, N. K. in Rothman, M. (2001). Recommendations on health-related quality of life research to support labeling and promotional claims in the United States. Quality of Life Research, 9, 887-900.

Rifel, J. (2006). Splošni večdimenzijski vprašalniki za merjenje kakovosti življenja [Generic multidimensional quality-of-life instruments]. Medicinski Razgledi, 45, 287-292.

Rutar, M. (2007). Kvaliteta življenja in subjektivno blagostanje pri bolnikih s kronično vnetno črevesno boleznijo [Quality of life and subjective wellbeing of patients with infalmmatory bowel disease] (neobjavljeno diplomsko delo). Filozofska fakulteta Univerze v Ljubljani, Slovenija.

Sonc, M., Vidmar, G. in Hlebš, S. (2010). Zanesljivost in veljavnost $\mathrm{V}$ slovenščino prevedenega vprašalnika o težavah zaradi fibromialgije [Reliability and validity of the slovenian translation of the fibromyalgia impact questionnaire]. Rehabilitacija, 9(1), 23-29.

Soni, R. K., Weisbord, S. D. in Unruh, M. L. (2010). Healthrelated quality of life outcomes in chronic kidney disease. Current Opinion in Nephrology and Hypertension, 19, 153-159.
Stavem, K. in Ganss, R. (2006). Reliability and validity of the ESRD Symptom Checklist - Transplantation Module in Norwegian kidney transplant recipients. $B M C$ Nephrology, 7, 17.

Statistični urad Republike Slovenije (2016). Prebivalstvo, staro 15 ali več let, po izobrazbi, starosti in spolu, Slovenija, letno. Ljubljana, Slovenija: avtor. Pridobljeno s: http:// pxweb.stat.si/pxweb/Dialog/varval.asp?ma $=05 \mathrm{G} 2002 \mathrm{~S}$ \&ti=\&path=../Database/Dem_soc/05_prebivalstvo/20_ soc_ekon_preb/01_05G20_izobrazba/\&lang=2

Svetičič, J. (2010). Preplet me $\bar{d}$ depresivnostjo in nekaterimi indikatorji telesnega zdravja starostnikov $v$ domu za starejše občane [Interplay among depression and physical health indicators of elders in residential care institutions] (neobjavljeno magistrsko delo). Filozofska fakulteta Univerze v Ljubljani, Slovenija.

Terwee, C. B., Bot, S.D.M., de Boer, M. R., van der Windt, D. V. A. M., Knol, D.L. Dekker, J. Bouter, L. M., de Vet, H. C. W. (2007). Quality criteria were proposed for measurement properties of health status questionnaire. Journal of Clinical Epidemiology, 60, 34-42.

Tonelli, M., Wiebe, N., Knoll, G., Bello, A., Browne, S., Jadhav, D., Klarenbach, S. in Gill, J. (2011). Systematic review: Kidney transplantation compared with dialysis in clinically relevant outcomes. American Journal of Transplantation, 11(10), 2093-2109.

Valderrábano, F., Jofre, R. in López-Gómez, J. M. (2001). Quality of life in end-stage renal disease patients. American Journal of Kidney Diseases, 38(3), 443-464.

Wainwright, S. P. (1999). Psychosocial recovery from adult kidney transplantation: A literature review. Journal of Clinical Nursing, 8(3), 233-245.

Žabjek, S. (2009). Kvaliteta življenja bolnikov s Parkinsonovo boleznijo [Quality of life in patients with Parkinson's disease] (Neobjavljeno diplomsko delo). Filozofska fakulteta Univerze v Ljubljani, Slovenija. 